\title{
STOPY ZWROTU \\ A WARTOŚĆ FUNDAMENTALNA SPÓŁEK W ŚWIETLE ZALOŻENIA O RACJONALNOŚCI INWESTORÓW
}

\section{WSTĘP}

Badania nad strategiami inwestycyjnymi, ich skutecznością czy efektywnościa rynku w absorpcji informacji od lat sa popularnym tematem zarówno badań naukowych, jak i poszukiwań inwestorów. Na giełdach papierów wartościowych obraca się wielkimi kwotami pieniędzy, rynki dają zarówno możliwość szybkiego zarobku, jak i narażają na potężne straty. Stąd emocje i zainteresowanie, które budza.

Teoretycznie rynek finansowy jest pośrednikiem pomiędzy dawcą kapitału a przedsiębiorstwem. Powstał po to, by finansować odważne pomysły i przedsięwzięcia oraz dawać możliwość partycypacji w ryzyku i osiagniętych zyskach. W związku z tym, przy założeniu, że inwestorzy są racjonalni i dobrze poinformowani, na ogół powinni oni chętniej lokować środki w spółkach, które w przyszłości będą dobrze funkcjonować i konsekwentnie podnosić swoją wartość. Zatem wzrost popytu na akcje spółki powinien wiązać się z oczekiwaniem zysków w przyszłości.

Jednak w miarę wzrostu złożoności rynków finansowych zależność między inwestorem a spółką zmalała. Mimo że kondycja giełd jest powszechnie uznawanym barometrem gospodarki, na rynkach światowych obserwuje się od wielu lat stopniowe rozejście się gospodarek realnych i rynków finansowych. Co do zasady, jeśli inwestorzy wykazuja zainteresowanie danym walorem i jego cena rośnie, to teoretycznie oznacza to, że oczekują wzrostu wartości swojej inwestycji. Jednak rozwój technologii oraz wzrost złożoności instrumentów finansowych spowodowały, że sa oni coraz mniej świadomi, w jakich przedsięwzięciach właściwie lokują kapitał, a ceny na rynkach finansowych coraz bardziej odrywają się od fundamentalnej wartości firmy. Kolejnym problemem jest cała gama psychologicznych efektów, które podkopują newralgiczne założenie teorii finansów o racjonalności uczestników systemu gospodarczego.

Celem niniejszego artykułu jest ocena zależności między stopa zwrotu z akcji a wynikami spółek w kolejnych okresach. Autorka proponuje hipotezę, że zależność między stopa zwrotu z udziałów w danym przedsiębiorstwie a jego kondycją finansową w późniejszym okresie nie występuje lub jest słaba. 
Hipoteza taka jest stawiana wbrew teorii klasycznej, głoszącej, że uczestnicy rynku zachowują się racjonalnie, jednakowo odczytując docierające do nich informacje, prawidłowo oceniając ich wpływ i maksymalizując zysk przez dobór najbardziej atrakcyjnych spółek do portfela. Cel niniejszego opracowania można również określić jako badanie założenia o racjonalności uczestników rynku w rozumieniu teorii klasycznej. Stawiana jest bowiem hipoteza, że nie maksymalizują oni zysku rozumianego jako przyszłe zyski netto danego przedsiębiorstwa, zatem nie są racjonalni w klasycznym ujęciu.

\section{PROCES PODEJMOWANIA DECYZJI PRZEZ INWESTORÓW A TEORIA KLASYCZNA}

W ekonomii funkcjonuje kilka modeli rynków finansowych, jednakże dotychczas największą rolę odgrywały teorie bazujące na założeniu racjonalności uczestników rynku. Racjonalni inwestorzy podejmuja decyzje, maksymalizując oczekiwaną użyteczność, co przeważnie sprowadza się do problemu optymalizacji w sensie Pareto z perspektywy stopy zwrotu oraz ryzyka. Bazuja oni na dostępnych informacjach i na ich podstawie zawsze dokonuja adekwatnej wyceny walorów. Ceny akcji nie zależą zatem od subiektywnych ocen czy preferencji, ale oparte sa na analizie informacji, które są tak samo postrzegane przez wszystkich uczestników rynku. W ekonomii klasycznej uznaje się, że inwestorzy racjonalni stanowią przeważającą większość, zatem ewentualne anomalie są szybko eliminowane przez mechanizmy arbitrażowe ${ }^{1}$. Nieracjonalność inwestorów ma charakter losowy, dzięki czemu jej wpływ sam się neutralizuje. W konsekwencji uzyskanie ponadprzeciętnych zysków w długim okresie okazuje się niemożliwe.

Sposób, w jaki inwestorzy podejmują decyzję co do akceptowanego ryzyka i pożądanego zysku, opisuje funkcja użyteczności dochodu. Na wykresie 1 przedstawiono krzywe obojętności, które odpowiadaja jednakowym poziomom zadowolenia inwestora. Różnią się one od klasycznych krzywych obojętności w teorii konsumenta, ponieważ jedna z osi (tutaj oś odciętych) reprezentuje dobro niechciane, czyli ryzyko. W przeciwieństwie do klasycznego dylematu wyboru między dwoma pożądanymi dobrami, teoria użyteczności w kontekście portfela inwestycyjnego rozpatruje wybór inwestycji, która jest kombinacja dobra chcianego (zysku) i niechcianego (ryzyka).

Poruszając się w obrębie tej samej krzywej obojętności, inwestor jest tak samo zadowolony z dokonanej inwestycji. Kształt krzywej informuje o stosunku inwestora do ryzyka - im bardziej stroma, tym większa awersja do ryzyka, ponieważ ta sama zmiana w poziomie ryzyka musi być zrekompensowana większym wzrostem rentowności. Kluczowy jest fakt, że przy niezmienionym poziomie ryzyka, inwestor zawsze będzie preferował wyższą stopę zwrotu. Wniosek taki płynie wprost z założenia o racjonalności inwestora - przedkłada on większe zyski nad mniejszymi, a pewne korzyści nad wątpliwymi.

${ }^{1}$ H. M. Markowitz, Portfolio selection, „Journal of Finance” 7(1), 1952, s. 77-91. 


\section{Wykres 1}

Krzywe obojętności i krzywa minimalnego ryzyka

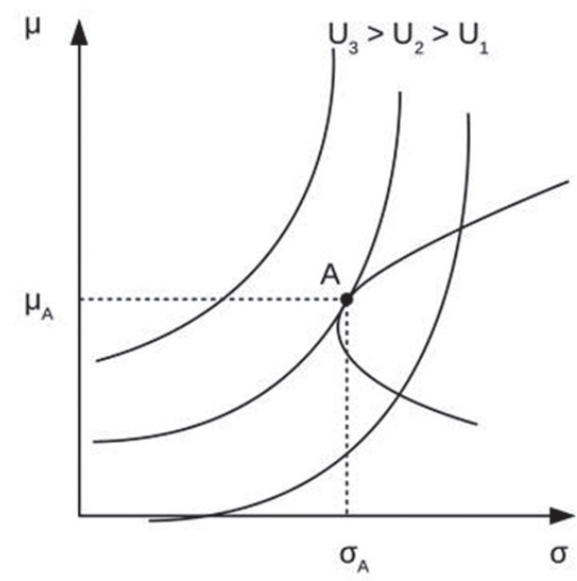

Źródło: opracowanie własne.

Historycznie jedna z ważniejszych teorii w finansach - bazujaca na klasycznej koncepcji racjonalności - była zaprezentowana w 1952 r. teoria portfela stworzona przez Harry'ego Markowitza². W myśl teorii Markowitza racjonalny uczestnik rynku inwestuje swój kapitał tak, by maksymalizować stopę zwrotu przy zadanej wariancji (interpretowanej jako miara ryzyka) bądź minimalizować wariancję przy zadanej stopie zysku. Teoria portfela Markowitza znajduje zastosowanie w optymalizacji portfela inwestycyjnego. Optymalny portfel uzyskuje się, nakładając krzywe obojętności na krzywą minimalnego ryzyka. Górna część krzywej minimalnego ryzyka nazywana jest granica portfeli efektywnych. Przynoszą one najniższe ryzyko przy danej stopie zwrotu oraz najwyższą stopę zwrotu przy zadanym ryzyku. Punkt styku granicy portfeli efektywnych i krzywej obojętności inwestora określa optymalny portfel z perspektywy relacji zysku do podejmowanego ryzyka.

Kolejną teorią silnie osadzoną na założeniu racjonalności inwestorów jest hipoteza o efektywności rynku kapitałowego. Na rynku efektywnym „ceny zawsze w pełni odzwierciedlają dostępne informacje" ${ }^{3}$. Taka definicja rodzi poważne konsekwencje, ponieważ oznacza, że rynek zawsze prawidłowo ustala ceny akcji, które są zupełnie niezależne od indywidualnych, subiektywnych preferencji zarówno inwestorów, jak i emitentów. Ponadto wszyscy gracze postrzegaja napływające informacje w ten sam sposób, natychmiast uwzględniajac je w swoich decyzjach inwestycyjnych.

2 Ibidem.

${ }^{3}$ E. Fama, Efficient capital markets: a review of theory and empirical work, „Journal of Finance" 25(2), 1970, s. 383-417. 
W kontekście badania, bazując na teorii klasycznej, należałoby przyjąć założenie o istnieniu istotnej korelacji pomiędzy stopami zwrotu a wynikami spółek w kolejnych okresach. Kurs akcji powinien odzwierciedlać wewnętrzna wartość firmy, a zatem również jej kondycję. Zainteresowanie firmą rośnie, gdy rosną oczekiwania co do wzrostu jej wartości. Decydujący się na zakup inwestorzy stają się współwłaścicielami spółki i oczekuja, że firma będzie się rozwijać (w granicach akceptowanego przez nich ryzyka), co da większe szanse na zyski w przyszłości. Rosnący popyt na dane akcje podnosi ich cenę, by ta - zgodnie z klasycznym modelem działania rynku - mogła ustabilizować się w stanie równowagi rynkowej. Racjonalni inwestorzy decydują się na zakup spółek, które przyniosa największe korzyści w kolejnym okresie (aż do pojawienia się kolejnych nowych informacji, mogących zmienić ich wycenę). Jeśli zatem inwestorzy sa dobrze poinformowani i starają się racjonalnie dobierać spółki do swoich portfeli, powinni skupiać swoje zainteresowanie na tych, które (w ich ocenie) w kolejnych okresach okażą się lepsze niż pozostałe.

\section{MOŻLIWE PRZYCZYNY BRAKU ZALEŻNOŚCI MIĘDZY STOPAMI ZWROTU A WYNIKAMI SPÓŁEK}

John M. Keynes ${ }^{4}$ porównywał inwestowanie na giełdzie do konkursu piękności, w którym nie wygrywa ani najpiękniejsza kandydatka, ani nawet ta, która publiczność uznała za najpiękniejszą. Wygrywa ta, którą większość uzna za najatrakcyjniejszą dla pozostałych głosujących. Inwestor może osiagnąć ponadprzeciętne zyski, jeśli jego oczekiwania sa inne niż oczekiwania pozostałych uczestników rynku, a przy tym - w przeciwieństwie do pozostałych uczestników - ma on rację. Gdyby jego oczekiwania były zgodne z oczekiwaniami innych, akcje, którymi się interesuje, już byłyby drogie, co uniemożliwiłoby realizację wysokich zysków. Mechanizm tworzenia się kursu akcji nie alokuje więc kapitału inwestycyjnego w pełni efektywnie, celem inwestora nie jest bowiem znalezienie spółki, która ma najlepsze perspektywy rozwoju, ale takiej, której cena najbardziej wzrośnie. Oznacza to, że celem nie jest dobrze funkcjonująca firma, tylko taka, która będzie (ale obecnie nie jest) za taka uważana. Zatem już na poziomie mechanizmu rynkowego mogą pojawić się odstępstwa od klasycznie rozumianego modelu.

Ponadto rozwój rynków finansowych spowodował oddalenie się kapitałodawcy od przedsięwzięcia, które finansuje. Inwestorzy instytucjonalni, niedysponujacy swoimi środkami, sa w zdecydowanej przewadze nad indywidualnymi ${ }^{5}$. Coraz większą popularność zyskuja produkty strukturyzowane, ubezpieczeniowe fundusze kapitałowe czy inne instrumenty, które klienci często nabywają bez świadomości, dokąd finalnie trafiają ich pieniądze. Znaczący

${ }^{4}$ J. M. Keynes, The General Theory of Employment, Interest and Money, Harcourt Brace and Co., New York 1936, rozdz. 12.

${ }^{5}$ Inwestorzy w Obrotach Giełdowych - podsumowanie badania, Giełda Papierów Wartościowych w Warszawie. 
jest również rozwój rynku instrumentów pochodnych, będących z jednej strony doskonałym narzędziem zabezpieczającym przed ryzykiem (np. kursu walutowego czy stopy procentowej), jednak równocześnie silnie zmniejszających przejrzystość operacji finansowych. Krótka sprzedaż umożliwiła transakcje na walorach, których nie mamy w posiadaniu, a dzięki swapom kredytowym (ang. credit default swap - CDS) można dowolnie transferować ryzyko udzielonych kredytów. Poprzez operacje sekurytyzacji można również wyizolować kredyty z bilansów banków i odsprzedać je w formie papierów wartościowych. Klient nabywający papier wartościowy pochodzący z sekurytyzacji aktywów banku rzadko jest świadom, jakiego rodzaju kredyty są bazą jego inwestycji. Co więcej, operacje tego typu powoduja, że bilanse banków również stają się mniej czytelne.

Mimo swojej spójności i przejrzystości ekonomia neoklasyczna była wielokrotnie kwestionowana i podważana. Krytyka dotyczyła m.in. zbyt licznych założeń, które mocno upraszczając rzeczywistość, w efekcie zniekształcają złożony obraz współczesnych rynków finansowych. Duży udział w kwestionowaniu klasycznych koncepcji ma ekonomia behawioralna. Jest to dziedzina ekonomii konfrontująca wyniki badań psychologicznych i socjologicznych z tezami ekonomii klasycznej. Teorie budowane w ramach ekonomii behawioralnej podaja w wątpliwość założenie o racjonalności inwestorów, wskazując na duży udział różnego rodzaju efektów psychologicznych w procesie podejmowania decyzji ${ }^{6}$. Okazuje się bowiem, że te same kwoty (w wartościach bezwzględnych) moga mieć różną użyteczność, a inwestorzy mogą preferować niższe stopy zwrotu z nieracjonalnych i - co istotne - mało przewidywalnych przyczyn. W mocy jednak pozostaje pytanie, czy czynniki te sa w stanie w długim okresie zaburzyć tradycyjne prawidła działania rynków finansowych. W niniejszym badaniu postawiono hipotezę, że inwestorzy nie maksymalizują zysku rozumianego jako przyszłe zyski netto zakupionej spółki, czyli nie są racjonalni w świetle klasycznej teorii ekonomii. Efekty behawioralne moga pomóc w wyjaśnieniu tego typu zachowań podważających powszechność klasycznych praw rynku.

\section{METODYKA BADANIA}

Przedmiotem badania są spółki notowane na Giełdzie Papierów Wartościowych w Warszawie na rynku głównym. Analizowano sprawozdania kwartalne oraz notowania na koniec kwartałów z lat 1998-2015. W analizie uwzględniono 458 spółek. Łącznie w badaniu wykorzystano 16079 sprawozdań kwartalnych. Jednakże przy części analiz zbiór ten uległ pomniejszeniu ze względu na konieczność obliczenia stóp zwrotu za kilka kwartałów dla każdej ze spółek. Badanie można uznać za pełne, ponieważ uwzględnia wszystkie notowane obecnie $^{7}$ na Giełdzie Papierów Wartościowych w Warszawie spółki.

\footnotetext{
6 Ibidem.

7 Grudzień 2015.
} 
W tabeli 1 zaprezentowano sektorową charakterystykę badanych spółek. Analiza objęła spółki z wielu różnych sektorów, jednak w uwzględnionej próbie przeważa przemysł. W relacji do udziału w gospodarce nadreprezentowane sa budownictwo i finanse (udział w gospodarce obu tych sektorów jest mniejszy niż 10\%) ${ }^{8}$. Tak duży udział przemysłu, budownictwa i finansów (głównie banków) ma związek z efektami skali - spółki notowane na Giełdzie Papierów Wartościowych to największe przedsiębiorstwa w kraju, a wymienione sektory wymagają przeciętnie większych nakładów kapitałowych niż handel czy informatyka.

Tabela 1

Podział badanych spółek ze względu na sektory

\begin{tabular}{|l|c|}
\hline \multicolumn{1}{|c|}{ Sektor } & Udział procentowy w próbie \\
\hline Przemysf $^{a}$ & 31,4 \\
\hline Budownictwo, deweloperzy & 15,1 \\
\hline Finanse & 13,1 \\
\hline Handel & 11,4 \\
\hline Informatyka, telekomunikacja & 9,0 \\
\hline Pozostałe $^{b}$ & 20,1 \\
\hline
\end{tabular}

a Elektromaszynowy, spożywczy, metalowy, materiałów budowlanych, farmaceutyczny, lekki, paliwowy, chemiczny, lekki, surowcowy, tworzyw sztucznych, drzewny i papierniczy, motoryzacyjny, inne. Media, energetyka, hotele i restauracje, ochrona zdrowia, recykling, inwestycje, inne.

${ }^{b}$ Media, energetyka, hotele i restauracje, ochrona zdrowia, recykling, inwestycje, inne.

Źródło: opracowanie własne.

Ponadto dokonano analizy próby ze względu na przychody. W Polsce, zgodnie z ustawą o swobodzie działalności gospodarczej, ze względu na przychody wyróżnia się następujące grupy przedsiębiorstw:

- duże - powyżej 50 mln EUR przychodu rocznie,

- średnie - od 10 do 50 mln EUR przychodu rocznie,

- mikro- i małe - poniżej 10 mln EUR przychodu rocznie.

W tabeli 2 przedstawiono klasyfikację spółek ze względu na przychody zgodnie z podziałem z ustawy o swobodzie działalności gospodarczej, przy czym w grupie największych firm dodatkowo wyróżniono spółki bardzo duże (ponad $500 \mathrm{mln}$ PLN przychodów rocznie). Duże spółki to połowa analizowanych przedsiębiorstw $i$ jest to nadreprezentacja w relacji do udziału w wytwarzanym PKB. Natomiast brak w próbie mikrofirm, które generują prawie 1/3 PKB Polski ${ }^{9}$. Jest to jednak zrozumiałe, biorąc pod uwagę duże koszty wejścia na rynek giełdowy.

\footnotetext{
8 Główny Urząd Statystyczny.

9 Główny Urząd Statystyczny.
} 
Tabela 2

Podział spółek ze względu na wielkość przychodów ${ }^{a}$ w 2014 r. ${ }^{b}$

\begin{tabular}{|l|c|}
\hline \multicolumn{1}{|c|}{ Wielkość spółki } & Udział procentowy w próbie \\
\hline Powyżej 500 mln PLN (duże) & 34,7 \\
\hline Od 215 do 500 mln PLN (duże) & 14,5 \\
\hline Od 43 do 215 mln PLN (średnie) & 32,9 \\
\hline Poniżej 43 mln PLN & 17,9 \\
\hline
\end{tabular}

a Sprawozdanie skonsolidowane, pozycja „Przychody ze sprzedaży”.

${ }^{b}$ Do obliczeń przyjęto kurs EUR/PLN równy 4,3.

Źródło: opracowanie własne.

Badanie będzie przeprowadzone metodami statystycznymi - weryfikowane będą hipotezy o istnieniu zależności liniowej (korelacji Pearsona) między stopami zwrotu z akcji spółek a ich wynikami bilansowymi w kolejnych okresach.

W badaniu kondycja spółek będzie mierzona na dwa sposoby. Po pierwsze, jako zmiana poziomu zysku na zainwestowanego złotego, po drugie, jako przyrost wartości księgowej na zainwestowanego złotego. Pierwszy wskaźnik wzrost lub spadek zysku na zainwestowanego złotego - można interpretować jako stopę zwrotu z zainwestowanego kapitału. Wskaźnik taki mówi o tym, ile zysku netto przypada na jednego zainwestowanego złotego i w ujęciu procentowym jest rentownościa inwestycji. Jest to odwrotność często stosowanego wskaźnika cena/zysk. Wzrost tego wskaźnika informuje o rosnącym zainteresowaniu inwestorów danym walorem, ponieważ są oni skłonni płacić więcej za ten sam poziom zysku z akcji. Wysoki poziom wskaźnika na tle średniej wartości dla branży może oznaczać przewartościowanie waloru. Na potrzeby badania użyto relacji w formie rentowności zainwestowanego kapitału, gdyż wydaje się, że bardziej odpowiada intuicji, iż wzrost kursu akcji pociaga za sobą wzrost wskaźnika.

Kondycję przedsiębiorstwa mierzy się nie tylko generowanym zyskiem. Firmy w fazie intensywnego rozwoju dużo inwestuja, mają wysokie koszty, ich wartość rośnie, ale zysk pozostaje niski. Dlatego poza wskaźnikiem ceny do zysku stosuje się również wskaźnik ceny do wartości księgowej. Oblicza się go, dzieląc kapitalizację spółki przez aktualną wartość księgową jej kapitałów własnych (czyli sumę aktywów pomniejszoną o zobowiązania ogólne). Wskaźnik ten nie powinien być rozpatrywany w oderwaniu od średnich wartości dla sektora. Przedsiębiorstwa produkcyjne posiadające rozbudowane parki maszynowe czy fabryki mają zdecydowanie wyższą wartość księgową niż np. firmy informatyczne czy doradcze - nawet przy zbliżonej atrakcyjności inwestycyjnej. Na potrzeby badania wskaźnik ten sprowadzono do postaci porównywalnej dla różnych spółek przez przyjęcie zamiast wartości księgowej jej względnego przyrostu. Przyrost względny wartości księgowej spółki mówi, o ile procent spółka urosła w danym okresie. Zauważmy, że podobnie jak wskaźnik 
ceny do zysku, wskaźnik ten również można sprowadzić do formy rentowności. Dzieląc przyrost wartości księgowej przez kapitalizację, otrzymujemy stopę zwrotu, gdzie jako „zysk” z inwestycji przyjmuje się przyrost wartości księgowej kapitałów własnych spółki.

Niezależnie od ceny pojedynczej akcji danej spółki inwestor oczekuje, że zainwestowany kapitał będzie pomnażany. Ostatecznie dywidenda jest tylko pochodna zysku (wypłacana jest z zysku), dlatego jako pierwotną miarę korzyści, jakie inwestor osiaga, inwestując w dany walor, jest zysk netto, który wygenerował jego kapitał. Dobrze funkcjonujacca spółka może się rozrastać, reinwestując zysk. Może jednak zaistnieć sytuacja, gdy spółka intensywnie się rozwija, generuje duże koszty ze względu na inwestycje i nie wykazuje zysków. Taki wzrost powinien być widoczny w przyroście wartości spółki, który na potrzeby badania przybliżamy wartością księgową spółki. Dlatego zastosowano również druga miarę korzyści, jakie spółka przynosi inwestorowi, a mianowicie przyrost wartości księgowej na jednego zainwestowanego złotego. Wartość księgowa jest to różnica między aktywami a zobowiązaniami spółki, co ostatecznie równa się kapitałowi własnemu. Należy podkreślić, że jest to bardzo uproszczona forma wyceny spółki i ma liczne ograniczenia. Jednak na potrzeby tak szerokiej analizy można uznać, że przybliżenie wartości spółki wartością księgową jest wystarczające. Oba wskaźniki można interpretować jako rentowność zainwestowanego kapitału - mierzoną zyskiem netto lub przyrostem wartości. Analizowane stopy zwrotu zdefiniowane zostały jako procentowa zmiana ceny danego waloru między ostatnimi dniami dwóch kolejnych kwartałów, w których odbywają się notowania.

W wykonanych analizach wykorzystano bazy danych Thomson Reuters oraz Notoria. Baza danych Notoria umożliwia pobranie kwartalnych sprawozdań finansowych spółek wraz z obliczonymi wybranymi wskaźnikami finansowymi w wystandaryzowanym formacie. Natomiast bazę Thomson Reuters wykorzystano do pobrania kursów historycznych wszystkich obecnie funkcjonujących spółek notowanych na Giełdzie Papierów Wartościowych w Warszawie. Odpowiednie dane zaimportowano do programu R. Doboru narzędzia dokonano ze względu na jego efektywność przy obliczeniach na bardzo dużych ilościach danych oraz funkcjonalne pakiety statystyczne.

Kwartalnym sprawozdaniom przyporządkowano notowania kursu giełdowego danej spółki na koniec kwartałów. Obliczono kwartalne stopy zwrotu w okresach $t$ - 1 do $t$, jak zaznaczono na schemacie 1 . Stopy zwrotu obliczono jako zmianę wartości kursu od początku do końca kwartału. Dodatni znak stopy zwrotu na potrzeby badania interpretujemy jako decyzję inwestorów o zakupie akcji danej spółki i wzrost zainteresowania nia. Zakładamy, że chcąc maksymalizować swoje zyski, nabyli te właśnie walory, ponieważ przewidywali, że przyniosą one najwięcej korzyści. Rozważmy następująca sytuację: inwestorzy w okresie od $t$ - 1 do $t$ kupują akcje danej spółki. Popyt na nie rośnie, zatem cena na $\mathrm{w}$ momencie $t$ jest wyższa niż w momencie $t$ - 1 . Stopa zwrotu za okres $t$ - 1 do $t$ jest dodatnia. Jeśli inwestorzy byli dobrze poinformowani i maksymalizują swój zysk, w nieodległej przyszłości powinna być obserwowana poprawa funkcjonowania spółki, czyli korzyści dla inwestorów. Czas, 
jaki upływa od zakupu waloru do momentu, w którym zaczyna się obserwować korzyści z zakupu spółki to $n$. Moment ten może być odroczony w czasie lub nastapić zaraz po zakupie (dla $n=0$ ). Dlatego weryfikowana jest hipoteza o zależności zarówno dla wyników tuż po zakupie, jak i odroczonych o kilka kwartałów. Ponadto wprowadzono parametr $k$, który określa okres, przez jaki narastają korzyści. Może się bowiem okazać, że korzyści są znaczące, jednakże rozłożone w czasie. Zatem parametry $n$ i $k$ definiuja przedział czasu, kiedy obserwowany jest oczekiwany przez inwestora rozwój spółki. Jeśli $n$ wyniesie 4, oznacza to, że badamy, czy pojawiły się dodatkowe korzyści po roku (czterech kwartałach) od zakupu akcji. Jeśli $k$ wyniesie 4 i $n$ również wyniesie 4 , oznacza to, że badamy pojawienie się dodatkowych korzyści po roku od zakupu akcji przez kolejny rok.

\section{Schemat 1}

\section{Przedziały czasowe obliczanych wskaźników}

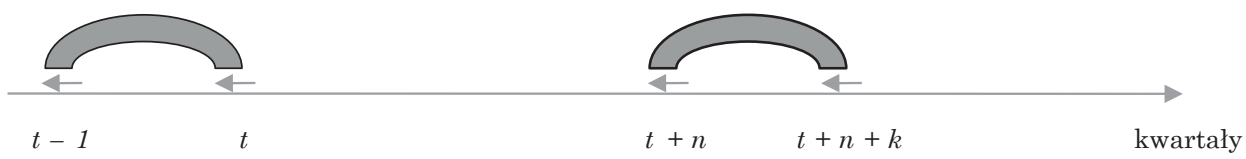

Źródło: opracowanie własne.

Należy zwrócić uwagę na fakt, że zysk na jednego złotego w okresie $t+n$ do $t+n+k$ jest sumowany, natomiast w przypadku wartości księgowej - obliczany jest jej przyrost względny od momentu $t+n$ do $t+n+k$ (różnica między wartością księgową na jednego złotego w okresie $t+n+k$ a wartością księgową na jednego złotego w okresie $t+n)$.

By zmierzyć badaną zależność, przyjęto zestaw wskaźników i metod pomiarowych. Do analizy zależności między stopami zwrotu a kondycją spółek w kolejnych okresach wykorzystano współczynnik korelacji Pearsona $r_{x y}$ wyrażony wzorem (1), mierzący poziom zależności liniowej między zmiennymi.

$$
r_{x y}=\frac{\sum_{i=1}^{n}\left(x_{i}-\bar{x}\right)\left(y_{i}-\bar{y}\right)}{\sqrt{\sum_{i=1}^{n}\left(x_{i}-\bar{x}\right)^{2}} \sqrt{\sum_{i=1}^{n}\left(y_{i}-\bar{y}\right)^{2}}},
$$

$x, y \quad$ - zmienne losowe,

$x_{i}^{\prime} y_{i}$ - wartości z prób $x, y$,

$\bar{x}, \bar{y} \quad$ - wartości średnie z prób $x, y$.

Należy jednak zwrócić uwagę na ograniczenia współczynnika korelacji Pearsona. W kontekście badania główną jego wadą jest zawężenie analizy do zależności liniowych, przy czym nieliniowe nie są w żaden sposób ujęte. Ponadto jest on podatny na skrajne obserwacje, które moga zaburzać wynik. Dlatego analizie zostanie poddany również wykres rozrzutu. 


\section{HIPOTEZY BADAWCZE}

Hipoteza zerowa zakłada, że nie występuje korelacja między stopą zwrotu z akcji a wybranym wskaźnikiem w kolejnych okresach. W badaniu zweryfikowano szereg hipotez, które różnią się między sobą rodzajem obliczanego wskaźnika (zysk na zainwestowanego złotego oraz przyrost wartości księgowej na zainwestowanego złotego) oraz przedziałami czasu, zilustrowanymi na schemacie 1.

Hipoteza zerowa $\mathrm{H}_{0}$ mówi o braku korelacji $\rho$ między notowaniami a wartościa wskaźnika w późniejszym okresie ( $\rho$ na poziomie statystycznie nieistotnie różnym od zera). Brak podstaw do odrzucenia hipotezy zerowej będzie oznaczał, że inwestorzy nie byli w stanie przewidzieć, które spółki przyniosą korzyści. Zakładamy bowiem, że inwestorzy podjęli racjonalne decyzje co do zakupu walorów, starając się dobrać jak najlepsze spółki. Dokonali wyborów swoich portfeli na podstawie przypuszczeń, że osiagna korzyści, nabywając wyselekcjonowane uprzednio akcje. Jeśli ich celem była maksymalizacja zysku, zakup tych właśnie akcji świadczy o tym, że są przekonani o ich przewadze nad innymi. Brak korelacji przy takich założeniach oznacza, że inwestorzy nie potrafili przewidzieć, jaka będzie kondycja spółek i nie byli w stanie podjać optymalnych decyzji.

Natomiast hipoteza alternatywna $\mathrm{H}_{1}$ zakłada istnienie korelacji $\rho$ między stopami zwrotu a wybranymi wskaźnikami na poziomie istotnie różnym od zera. Odrzucenie hipotezy zerowej na rzecz hipotezy alternatywnej będzie oznaczało, że zaistniała zależność (choćby słaba) między badanymi zmiennymi. Jednak tak sformułowana hipoteza alternatywna nie definiuje, czy inwestorzy dobrze przewidzieli trendy rynkowe. Ujemna korelacja wskazywać bowiem może, iż nabyli udziały mniej efektywnych spółek niż dobrane losowo. Przyjęcie hipotezy alternatywnej wskazywać może zatem na konieczność zbadania znaku korelacji i jej siły.

$$
\begin{aligned}
& \mathrm{H}_{0}: \rho=0 \\
& \mathrm{H}_{1}: \rho \neq 0
\end{aligned}
$$

Po wygenerowaniu danych dla odpowiednich wskaźników, wartości $n$ i $k$, przeprowadzono $\mathrm{w}$ programie $\mathrm{R}$ test korelacji za pomoca funkcji cor.test. Oblicza ona wartości estymowanej korelacji z przedziałami ufności na poziomie $95 \%$ oraz $p$-wartość. Wyniki poszczególnych testów przedstawiono w tabeli 1 i 2 . Do weryfikacji hipotez wykorzystano obliczone $p$-wartości. Przyjęto, że jeśli $p$-wartość jest większa niż 0,05 , to nie ma podstaw do odrzucenia hipotezy zerowej o braku korelacji. 


\section{WYNIKI}

Rezultaty badania korelacji między kwartalną stopą zwrotu z akcji a przyrostem zysku na zainwestowanego złotego przedstawiono w tabeli 3.

Tabela 3

Korelacje między stopami zwrotu a wskaźnikiem zysku na zainwestowanego złotego w $k$ kwartałach z opóźnieniem $n$

\begin{tabular}{|c|c|c|c|c|c|}
\hline $\boldsymbol{n} / \boldsymbol{k}$ & $\mathbf{1}$ & $\mathbf{2}$ & $\mathbf{3}$ & $\mathbf{4}$ & $\mathbf{8}$ \\
\hline 0 & $\mathbf{0 , 0 2 5}^{a}$ & $\mathbf{0 , 0 2 7}$ & $\mathbf{0 , 0 2 4}$ & $\mathbf{0 , 0 2 3}$ & $\mathbf{0 , 0 2 7}$ \\
\hline 1 & 0,021 & 0,017 & 0,018 & 0,020 & 0,022 \\
\hline 2 & 0,008 & 0,011 & 0,016 & 0,015 & 0,014 \\
\hline 3 & 0,009 & 0,015 & 0,016 & 0,016 & 0,012 \\
\hline 4 & 0,015 & 0,014 & 0,015 & 0,018 & 0,012 \\
\hline
\end{tabular}

${ }^{a} \mathrm{~W}$ tabeli pogrubiono wartości statystyk, dla których $p$-value była niższa niż 0,05 .

Źródło: opracowanie własne.

Prawie wszystkie zaprezentowane korelacje w przedziale ufności 95\% nie daja podstaw do odrzucenia hipotezy zerowej, że korelacja jest równa zeru. Przy braku opóźnienia testy wykazały korelację różne od zera ( $p$-wartość mniejsza niż 0,05), jednak żadna spośród estymowanych wartości korelacji nie przekracza 0,03 . Tak niską wartość estymowanej korelacji również można uznać za jej brak. Wykres 2 to wykres punktowy dla najwyższej wartości korelacji z tabeli 1 (dla $n=0$ i $k=2$ ), a wykres 3 to fragment wykresu o największym zagęszczeniu wartości (oś odciętych ograniczona od -1 do 1 , oś rzędnych ograniczona od $-0,5$ do 1 ). Do wygenerowania wykresów użyto pakietu ggplot 2 w programie R. Naniesione punkty mają podniesiony wspó1czynnik przejrzystości, by lepiej lokalizować skupiska punktów w obszarach o dużej gęstości.

Punkty koncentruja się wokół osi rzędnych, trudno się jednak dopatrzyć liniowej zależności. Średni zysk na zainwestowanego złotego (w dwóch kwartałach) wyniósł 0,012 zł (z odchyleniem standardowym 0,6 zł). Kształt chmury punktów nie wskazuje na istnienie zależności liniowej pomiędzy stopa zwrotu z akcji a zyskiem z dwóch kwartałów przypadającym na zainwestowanego złotego. 


\section{Wykres 2}

Rozrzut stopy zwrotu z akcji i zysku spółki na zainwestowanego złotego w kolejnych okresach (dla $n=0$ i $k=2$ )

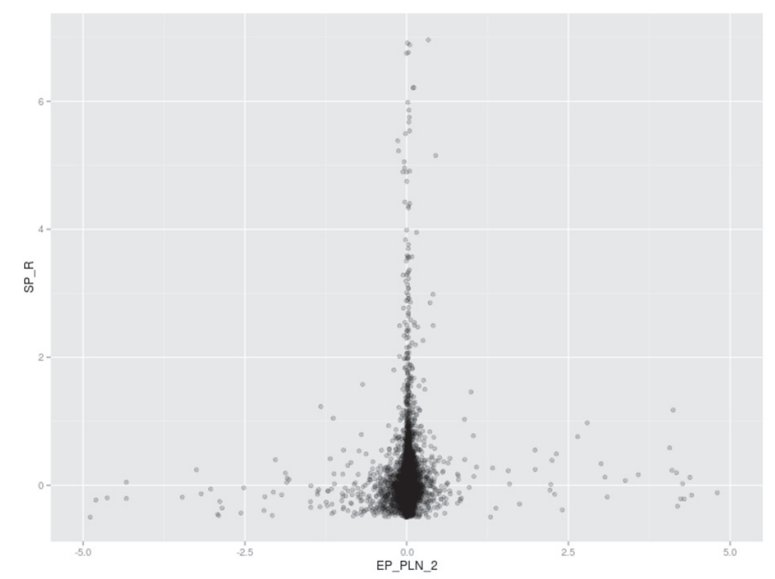

Źródło: opracowanie własne.

\section{Wykres 3}

Rozrzut stopy zwrotu z akcji i zysku spółki na zainwestowanego złotego w kolejnych okresach (dla $n=0$ i $k=2$ ), wycinek zależności

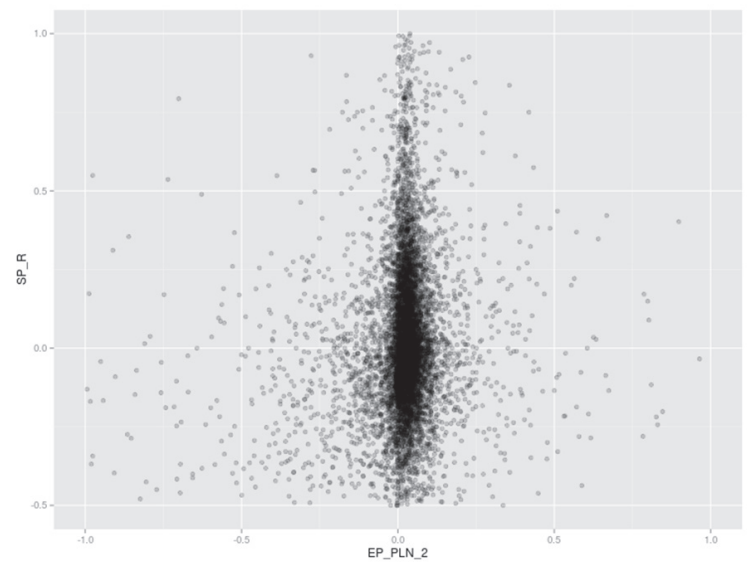

Źródło: opracowanie własne.

Podobną analizę przeprowadzono dla przyrostu wartości księgowej spółek. Badano korelację między stopami zwrotu z akcji a przyrostem wartości księgowej spółek na zainwestowanego złotego w $k$ kwartałach z opóźnieniem $n$ kwartałów. Wyniki zaprezentowano w tabeli 4. 


\section{Tabela 4}

Korelacje między stopami zwrotu a przyrostem wartości księgowej na zainwestowanego złotego w $k$ kwartałach z opóźnieniem $n$

\begin{tabular}{|c|c|c|c|c|c|}
\hline $\boldsymbol{n} / \boldsymbol{k}$ & $\mathbf{1}$ & $\mathbf{2}$ & $\mathbf{3}$ & $\mathbf{4}$ & $\mathbf{8}$ \\
\hline 0 & $-0,002$ & 0,000 & 0,000 & 0,000 & 0,002 \\
\hline 1 & 0,002 & $-0,002$ & 0,000 & 0,000 & 0,004 \\
\hline 2 & 0,009 & 0,002 & $-0,002$ & 0,000 & 0,005 \\
\hline 3 & 0,000 & 0,012 & 0,000 & $-0,002$ & 0,003 \\
\hline 4 & 0,016 & 0,002 & 0,012 & 0,003 & 0,000 \\
\hline
\end{tabular}

Źródło: opracowanie własne.

Na poziomie istotności $95 \%$ nie ma podstaw do odrzucenia hipotezy zerowej o braku zależności liniowej. Korelacja we wszystkich przypadkach jest bardzo bliska zeru. Podobnie jak w przypadku zysku na złotego, wygenerowano również wykresy dla najwyższej wartości z tabeli 4 . Najwyższa, choć wciąż śladowa, korelacja wystapiła w przypadku opóźnienia równego rok i obliczeń przeprowadzonych dla jednego kwartału $(n=4$ i $k=1)$. Na wykresie 4 zaprezentowano wygenerowany w pakiecie ggplot 2 wykres, a na wykresie 5 przedstawiono zbliżenie na fragment wykresu o najwyższym zagęszczeniu punktów (oś odciętych ograniczona od -1 do 1 , oś rzędnych ograniczona od $-0,5$ do 1 ).

\section{Wykres 4}

Rozrzut stopy zwrotu z akcji i przyrostu wartości księgowej spółki na zainwestowanego złotego w kolejnych okresach (dla $n=4$ i $k=1)$

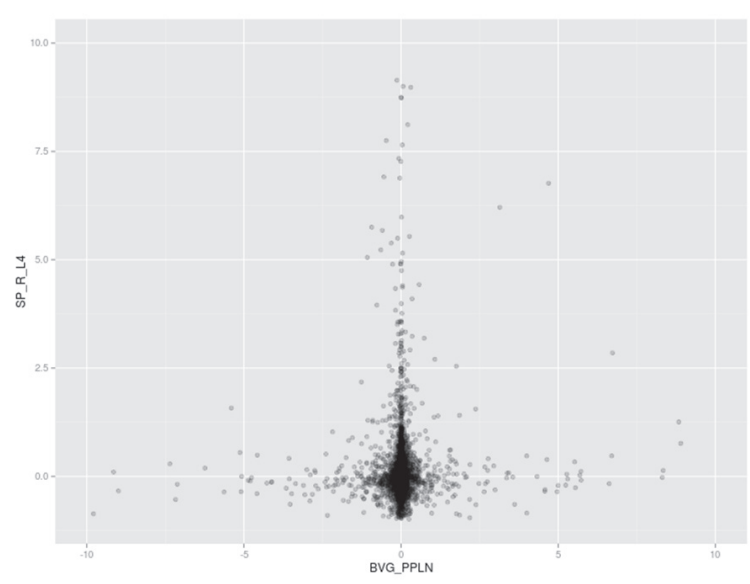

Źródło: opracowanie własne. 


\section{Wykres 5}

Rozrzut stopy zwrotu z akcji i przyrostu wartości księgowej spółki na zainwestowanego złotego w kolejnych okresach (dla $n=4$ i $k=1$ ), wycinek zależności

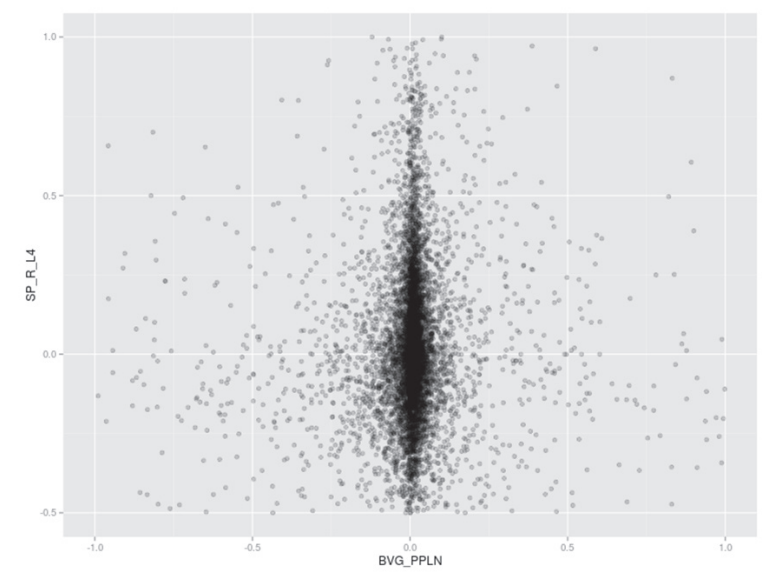

Źródło: opracowanie własne.

W przypadku przyrostu wartości księgowej na zainwestowanego złotego również nie obserwuje się wyraźnych zależności liniowych. Średni przyrost wartości w jednym okresie wyniósł 0,00 zł przy odchyleniu standardowym $1,88 \mathrm{zl}$.

\section{WNIOSKI}

W przeprowadzonych analizach nie zaobserwowano liniowej zależności między stopami zwrotu z akcji a korzyściami z tych akcji w kolejnych okresach (mierzonych zyskiem netto oraz przyrostem wartości księgowej inwestycji). Może to oznaczać, że przyszłe wyniki spółek nie są głównym czynnikiem decydującym o tym, na które akcje rośnie popyt i które z nich drożeją. Potwierdzono wyjściowo postawioną hipotezę o braku korelacji, a zarazem podważono założenie o racjonalności inwestorów.

Taki rezultat może oznaczać rzeczywisty brak zależności, niemniej warto zauważyć, że pewne czynniki mogły zostać pominięte i zasadne jest pogłębienie badania. Na gruncie teorii klasycznej przyjmuje się dwa główne czynniki wpływające na atrakcyjność inwestycji - stopa zwrotu (zysk) oraz ryzyko. W badaniu pominięto aspekt ryzyka. Dana firma mogła utrzymać wyniki z poprzedniego okresu, jedocześnie redukując ryzyko, i w ten sposób zachęcić inwestorów do lokowania kapitału, nie wykazując zmian w zysku netto. Z perspektywy metodyki istotny może być fakt, że badana jest jedynie zależność liniowa, a rozważyć można również zależności nieliniowe. Ponadto współczyn- 
nik korelacji Pearsona przypisuje stosunkowo dużą rolę wartościom skrajnym, co również może zaburzać odczyt danych. Ponadto obliczane są korelacje pojedynczych wskaźników, a przeanalizować należałoby istnienie zależności między kombinacją obu wskaźników (np. model regresji).

Warto również rozważyć podział próby na mniejsze, ale bardziej jednolite podgrupy, wzięte do badania spółki są bowiem bardzo różnorodne. Istnieje możliwość, że zależności występuja, ale jedynie dla spółek dużych bądź małych, dla wybranego sektora lub tylko w pewnych okresach (kryzys mógł zaburzyć pewne zależności obserwowane w czasie koniunktury). Zależność może być np. mniejsza dla małych spółek, których walory są mniej płynne, bądź w okresie kryzysu, kiedy decyzjami inwestorów częściej kieruje strach niż racjonalne analizy. Kolejnym problemem mogą być wskaźniki, które sa tylko przybliżeniem korzyści, jakie miałby osiagnać inwestor. Tutaj warto rozważyć alternatywny dla tradycyjnego wskaźnika C/Z (cena do zysku) wskaźnik EV/EBITDA (kapitalizacja spółki do zysku operacyjnego powiększonego o amortyzację). Bierze on pod uwagę zadłużenie, ponadto EBITDA jest mniej podatna na manipulacje księgowe niż zysk netto. Zatem można by zastosować wskaźnik w formie rentowności - EBITDA na zainwestowanego złotego.

$\mathrm{Na}$ podstawie przeprowadzonego badania można wstępnie potwierdzić brak zależności liniowej, wszakże problematyka racjonalności inwestora, jak i zależności notowań giełdowych od wartości spółki powinna być dalej eksplorowana. Istnieje wiele argumentów kwestionujących zasadę, iż dobre spółki drożeja, a słabe tanieja, oraz wiele mechanizmów, które moga przyczyniać się do takiego stanu rzeczy. Kolejne badania oraz zastosowanie zaproponowanych powyżej zmian w metodyce może pomóc rozwiać wątpliwości.

mgr Alicja Fraś

Uniwersytet Ekonomiczny w Poznaniu

alicja.m.fras@gmail.com

\title{
RATES OF RETURN AND THE FUNDAMENTAL VALUE OF A COMPANY IN THE LIGHT OF THE ASSUMPTION OF INVESTOR'S RATIONALITY
}

\author{
Sum mary
}

If investors were rational, they would buy the stock of companies which in their opinion represent the highest probability of generating profit or value growth. Therefore a positive correlation between a share price increase (as an indicator of investors' confidence in the future prosperity of given company) and subsequent benefits should be evident. This, however, does not always happen. One of the reasons why this seemingly natural relation is not observed may be that investors do not always behave rationally. Another may be certain methodological issues discussed in the article. The research presented was based on a sample of 458 companies listed on the Warsaw Stock Exchange. The time period covered the years 1998-2015. It has been found that there is no linear dependency between quotations and the company's end results understood as income per invested zloty and book value growth per invested zloty. The outcome of the research may have been disturbed by methodological factors, therefore in the research to follow different risks, including differences in subgroups (sectors, small and big firms) as well as other ratios will be taken into account and the non-linear dependency will be verified. 
